\title{
The Role of Inventories In the Business Cycle
}

BY AUBHIK KHAN

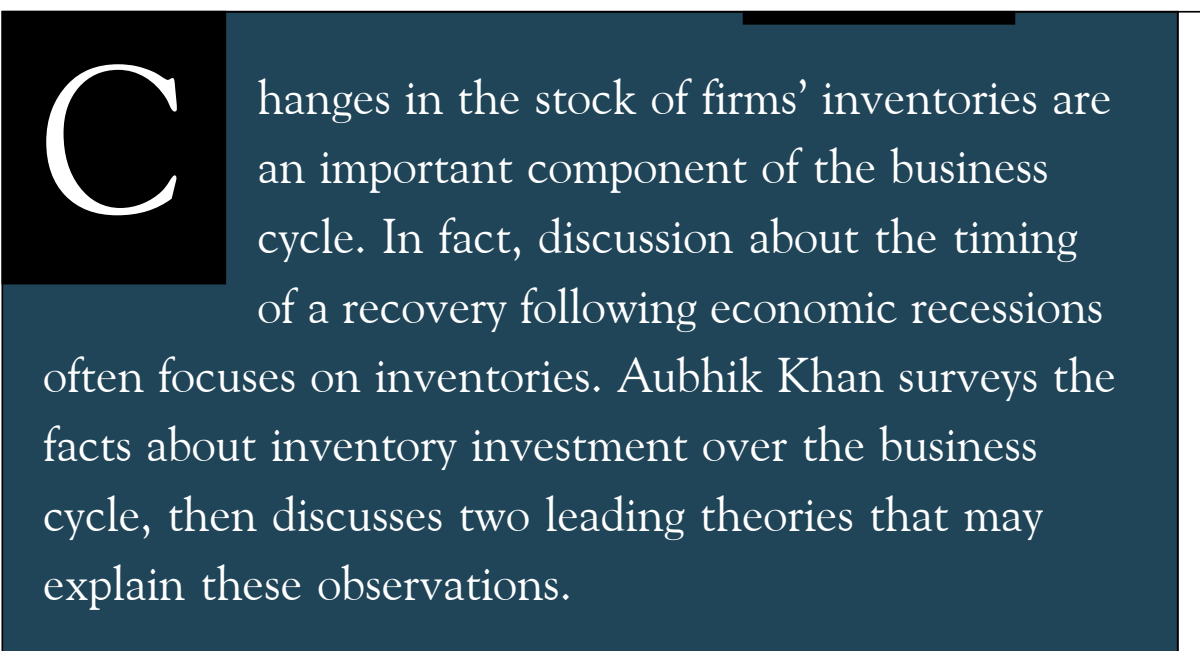

Changes in the stock of firms' inventories are an important component of the business cycle. Alan Blinder, a former Governor of the Federal Reserve System, famously remarked that "the business cycle, to a surprisingly large degree, is an inventory cycle." Consistent with this perspective, much of the discussion about the timing of a recovery following economic recessions focuses on firms' stocks of inventories. Pundits suggest that production and employment cannot recover until firms' inventories fall, relative to their sales.

This article surveys the facts about inventory investment over the business cycle, then discusses two leading theories of inventory investment

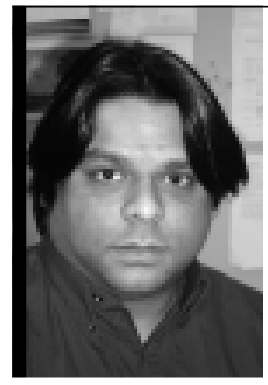

Aubhik Khan is a senior economist in the Research Department of the Philadelphia Fed. that may explain these observations. Theory that passes the test of observation may allow us, with some confidence, to predict future movements in the data. Theories that have sought to explain macroeconomic changes in inventory investment have generally focused on firms' attempts to (1) reduce the costs of adjusting their production level or (2) reduce the costs of placing orders for intermediate goods. While much of the research on inventories in the past 50 years has emphasized the cost of adjusting production, this approach has had well-known difficulties when confronted with the data. Recent work that has focused on reducing the fixed costs of ordering goods may provide a framework that is more consistent with the facts. At the same time, this recent work may produce new insights about the interaction between inventories and the macroeconomy. These two theories predict different behavior for aggregate production, sales, and inventory investment.
INVENTORIES SEEM TO BE IMPORTANT IN THE BUSINESS CYCLE

Figure 1 shows the businesscycle component of real gross domestic product (GDP) in the United States over most of the postwar period. We can think of movements in GDP as the sum of two components: the trend and the business cycle. The trend represents the average growth rate of the economy across surrounding years. The business cycle reflects short-term deviations from this trend: the expansions and contractions that make up the business cycle. ${ }^{1}, 2$ For comparison, recessions, as dated by the National Bureau of Economic Research, are shaded in the figure.

The figure also includes changes in the stock of private nonfarm inventories (private refers to nongovernment). The difference between GDP, the sum of all goods and services produced in the economy over a given period, and final sales, the sum of all goods and services sold, is known as net inventory investment. Net inventory

${ }^{1}$ Actually, any type of expenditure or output may be broken down into a business-cycle component and a trend. The process of isolating the business-cycle component is known as "detrending" or "filtering." The real quarterly series in the figure have been detrended with the Hodrick-Prescott filter using a smoothing parameter of 1600 . For additional details, see Edward C. Prescott's paper.

${ }^{2}$ It then follows that a recession, in this approach to business cycles, is a period in which the economy is growing at rates that are lower than its trend. This contrasts with the conventional use of the term recession to describe a period of negative growth. 
investment is a measure of goods that have been made but not sold to consumers nor used by a firm as an intermediate input into production.

A car made by Honda in Ohio, completed but retained unused in the factory, adds to Honda's stock of inventories. Steel bought by the same manufacturer but left unused is a raw material that also adds to Honda's stock of inventories. Nonfarm private inventories are essentially stocks of these final goods, intermediate inputs, materials, or supplies held by businesses. Changes in this component of total inventory investment account for most of the change in total inventories over the business cycle.

Cyclicality and Volatility. In organizing their thinking about the role of an economic variable such as inventory investment over the business cycle, economists focus on the cyclicality and volatility of the variable. A variable's cyclicality — formally, its correlation with real GDP — is a measure of how the variable changes over the business cycle. For example, net exports - that is, exports minus imports - are countercyclical: they fall as GDP rises during an expansion, and they rise as GDP declines in a recession.

In contrast, consumption and investment are pro-cyclical: they rise during expansions and fall, alongside GDP, in recessions. A significant correlation, whether positive or negative, between any economic variable and GDP suggests that the variable is cyclical in that it varies in a systematic way with GDP over the business cycle. This is not true of all economic variables. For example, government spending is acyclical: it shows no significant correlation with economy activity over the business cycle, neither rising nor falling systematically.

While the cyclicality of a variable measures the extent to which it rises or falls with GDP, volatility mea- sures the size of the variable's total fluctuation over the business cycle. ${ }^{3}$ Economic variables differ considerably in their volatility. For example, consumption of nondurable goods and services is far less volatile than GDP, while business investment and consumption of consumer durable goods are more volatile - i.e., they have bigger swings. Thus, investment fluctuates a lot more than does the consumption of nondurables and services as output rises and falls.

\section{Net inventory investment is} pro-cyclical (Figure 1). It moves along with GDP, rising during expansions and falling during recessions. This is a very important observation because it means

${ }^{3}$ Formally, we define volatility as the standard deviation of the business-cycle component of the quarterly data. that a common view of inventories that they are goods that firms were unable to sell - can't explain most of the movements in inventories. In an expansion, inventories grow as consumption and investment grow. That is, when sales rise, inventories also rise. If inventories were mainly goods that firms couldn't sell, they would tend to rise when sales fell.

By definition GDP $=$ Final

Sales + Net Inventory Investment. Thus, any change in GDP must be attributable to either a change in final sales or a change in net inventory investment. Let's look at the fraction of the change in GDP that can be accounted for by changes in net inventory investment. To accomplish this, we divide the change in inventories during recessions by the corresponding change in GDP. The result is a number around one-half. Almost half of the fall

\section{FIGURE 1}

\section{GDP, Final Sales, and Changes in Nonfarm In- ventories}

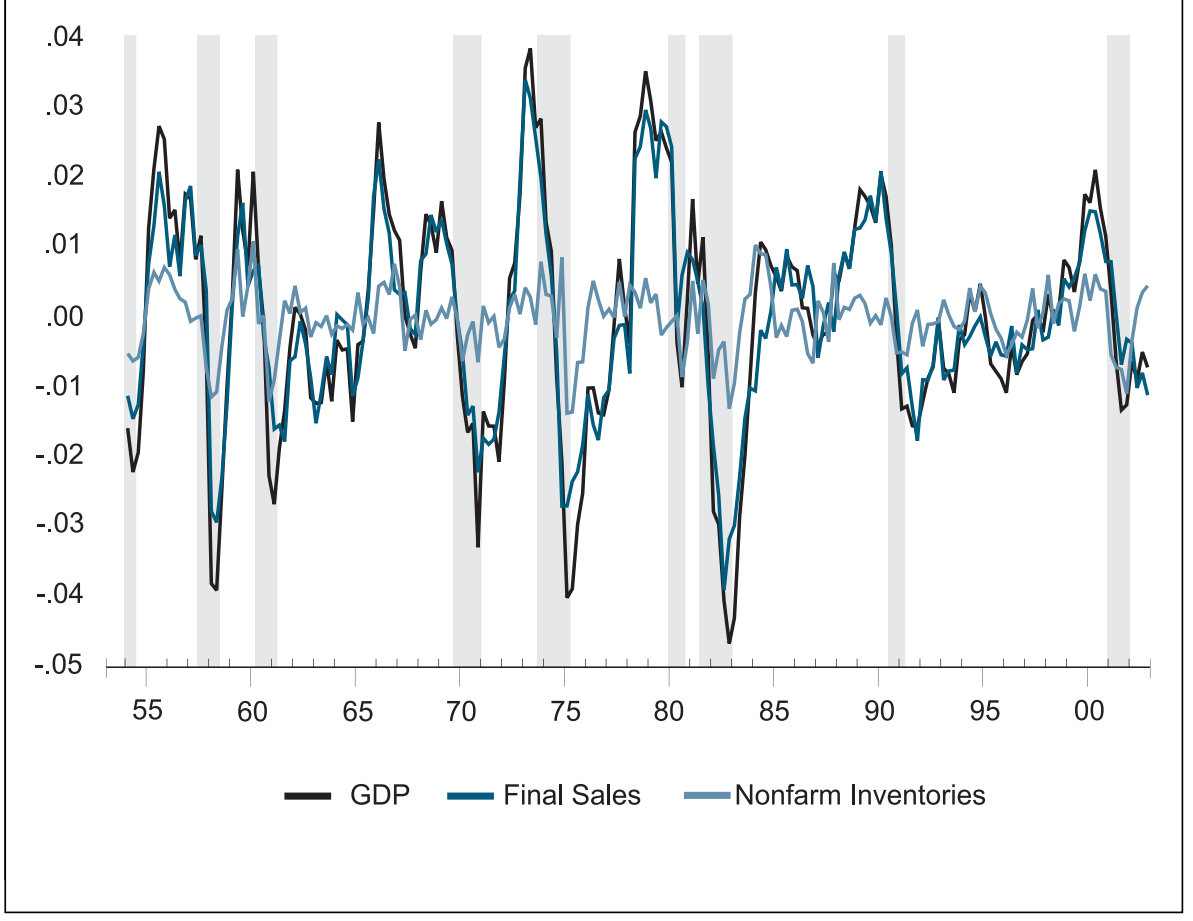


in production experienced by the U.S. economy during a recession may be explained by a reduction in net inventory investment. This is a surprisingly large fraction when one considers that net inventory investment is, on average, only around 0.5 percent of GDP. It indicates that inventory investment is extremely volatile.

\section{Adding to the Volatility of}

Output. The pro-cyclicality and extreme volatility of inventory investment have led researchers to suggest that inventories are a destabilizing force. At its simplest, their argument is as follows. Inventory investment and final sales tend to move together: both rise during expansions, and both fall during recessions. Consequently, GDP varies by more than it would if inventory investment were constant or negatively correlated with final sales.

To understand this better, consider the following simple example. If final sales rise during odd years and fall during even years, while inventory investment rises (by the same amount) during even years and falls during odd years, there's no effect on GDP. Inventory investment and final sales move in opposite directions; they are negatively correlated. As a result, each offsets the change in the other. Production is smoothed.

Now, consider an alternative case in which both series rise during odd years. Since inventory investment moves with output, and since it's highly volatile, inventories substantially raise the volatility of GDP. Since final sales and inventory investment are indeed positively correlated, typically rising and falling at the same time, researchers have concluded that inventories are a destabilizing force in the economy. (See Are Inventories Becoming Less Prominent?) Changes in inventories magnify the effect of a change in final sales on domestic production.

\section{THE MYSTERY OF INVENTORIES}

Economists are not satisfied merely to uncover the facts about inventories and the business cycle. Their primary goal is to explain these findings. Before we may begin to understand why firms change their holdings of inventories over the business cycle, we must have an understanding of why firms hold inventories at all. For economic theory, this has been more of a mystery than you might suppose.

Why would a firm produce goods but not sell them? Sales completed today give the firm income that it may invest. For example, even if the firm has no other immediate use for the funds, it might deposit them in an interest-earning account. A firm would forgo this interest income if it chooses not to sell its goods immediately.

But perhaps it isn't voluntary.

You may think firms hold inventories only of finished goods they have been unable to sell. While firms do sometimes accumulate inventories of unsold goods because of weaker-than-expected demand, this can't be the central explanation of inventory holdings. First, remember that inventories rise when sales do. Second, goods that have been produced but not yet sold are only a fraction of the total stock of inventories. Firms also hold inventories of inputs they use to produce their goods, buying them before they need them.

The answer to the question of why firms forgo interest income must involve benefits derived from holding inventories. Holding stocks of inventories must somehow reduce a firm's cost of production, and these cost savings must exceed the forgone interest.

There are two theories of how production costs induce firms to hold stocks of inventories. The first, known as the production-smoothing model of inventories, emphasizes the costs of adjusting production. The second, known as the $(S, s)$ model of inventories, emphasizes the costs of accepting deliveries. While each of these theories can explain why firms hold inventories, they are commonly applied to different types of inventories. Thus, the two theories are not mutually exclusive; both may be relevant to an understanding of the overall stock of inventories.

However, as with all science, the empirical relevance of these alternative theories can be assessed by evaluating their predictions against the data. The production-smoothing model and the (S, s) model generally have distinct predictions about the joint behavior of production, sales, and inventory investment.

\section{THE PRODUCTION- SMOOTHING MODEL}

The production-smoothing model explains why a manufacturing firm holds stocks of goods produced but unsold. The model assumes that it is costly for the manufacturing firm to adjust production.

It is costly to buy and install new equipment or to uninstall and sell off previously installed equipment. Workers are costly to hire and train, and layoffs are also expensive. Since changing levels of output often involve changing the size of the labor force and purchasing new capital equipment, these adjustment costs are inevitable for a firm that changes its level of output over time. It's reasonable to assume that these costs of changing production levels actually increase with the size of the change. For example, a large increase in production requires hiring more workers and, thus, involves higher training costs. In any case, given these costs of adjusting production, if sales are volatile, a firm may prefer not to vary production to match the variation in sales. Instead, it may use inventories of already produced goods to offset the difference between production and sales. 


\section{ARE INVENTORIES BECOMING LESS PROMINENT?}

If inventories are indeed a destabilizing element of aggregate economic activity, perhaps the much heralded improvements in technology that have led to sharp declines in the inventory to sales ratio will eventually yield a less severe business cycle. Since inventories seem to explain so much of the decline in output during recessions, and since they amplify the effect of changes in final sales on GDP, as inventory levels decline, perhaps GDP will be subject to less severe fluctuations.

Arguments such as this have led economists to emphasize the decline in the inventory to sales ratio. In Figure 2, we see the nominal stock of inventories as a ratio of final sales. Clearly, it has declined sharply since the early 1980s. Many observers have regarded this decline as the result of improvements in technology and management methods that have allowed firms to reduce their holdings of inventories relative to their sales. This is less clear from the figure. First, we see that the inventory to sales ratio rose sharply in the 1970s. If technological innovation has reduced the ratio since the 1980s, what was the sharp technological regress in the 1970s? Second, and related, is the finding that the inventory to sales ratio was as low in the late 1960s as it was in the mid 1980s.

Even the decline in the importance of inventories is less clear than is commonly acknowledged. The figure also plots the real inventory to sales ratio, that is, the ratio when both inventories and sales figures have been divided by their price indexes. While the nominal inventory to sales ratio shows a clear negative trend over the past 20 to 25 years, the real inventory to sales ratio displays no corresponding decline! This implies that the price index for inventories has fallen more slowly than that for final sales. It would seem that changes in the relative price of intermediate inputs and materials and supplies, both components of the overall stock of inventories but not part of final sales, must account for the divergence between the real and nominal ratios of inventories to sales.

While I cannot suggest which ratio is more sensible, Figure 2 casts some doubt on some of the discussion of technological improvements' role in reducing demand for inventories. While both the financial press and policymakers have repeatedly mentioned the important role of improved management techniques, such as just-intime production methods, in reducing firms' dependence on inventories, the real inventory to sales ratio in Figure 2 suggests caution before making sweeping generalizations. When examining the nominal inventory to sales ratio, we see that it rose before it fell, something that is hard to explain using technological improvement. The real ratio has not declined consistently over the past 20 years.

\section{FIGURE 2}

\section{Quarterly Nominal and Real Inventory to Sales Ratios}

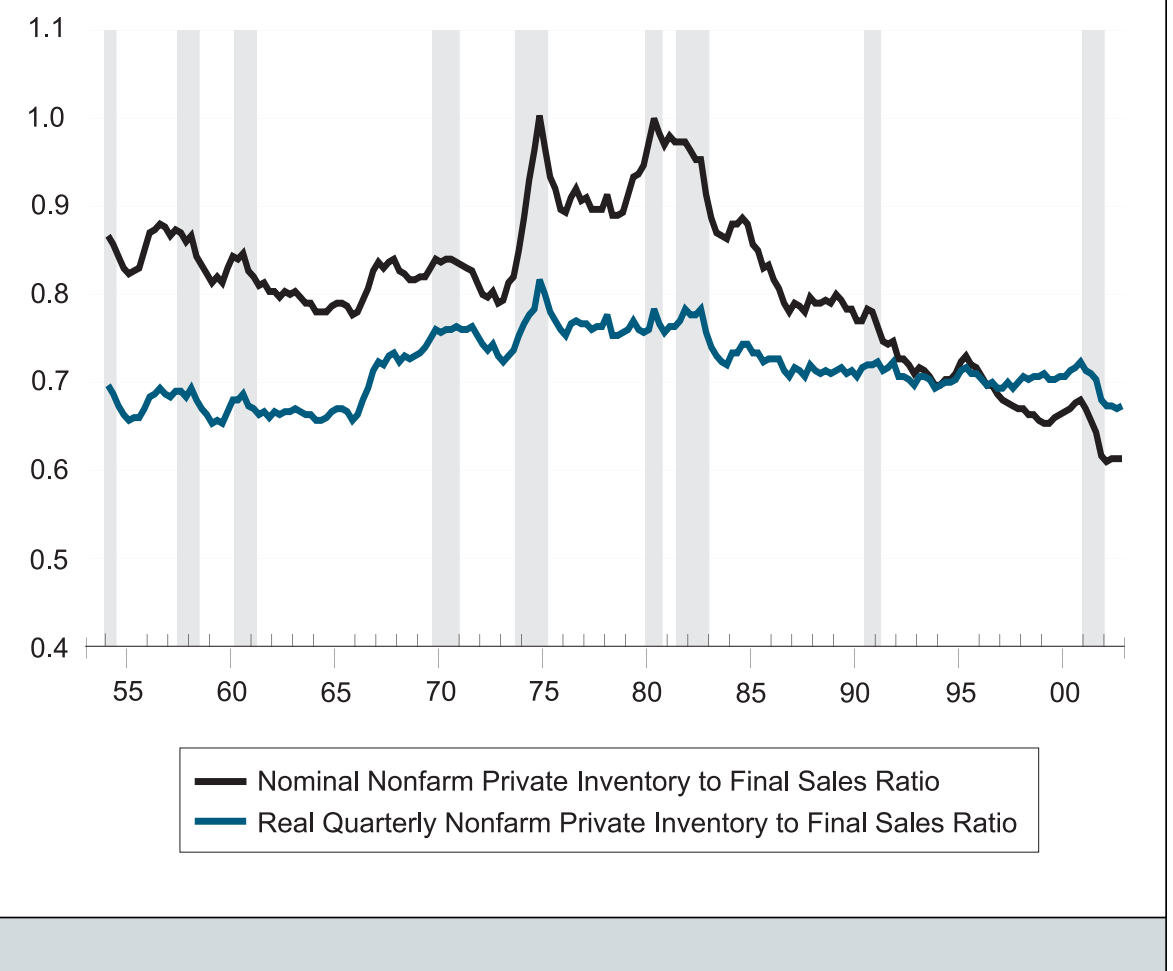


For example, a toy maker knows that sales are always higher during the Christmas season. However, since it is expensive to hire a large number of workers in the last quarter of the year, the toy company may produce more toys than it sells over the first nine months. During these nine months, production exceeds sales, and the toy company accumulates inventories. At the end of the year, when demand rises, the toy factory has fewer workers than it needs to satisfy sales. But even though production is lower than Christmas sales, the company can sell off its accumulated inventories to meet the increased demand. Accumulating inventories from January through September lets the toy maker smooth production relative to sales; that is, production is less volatile than sales, and when sales rise, inventories fall.

The defining assumption of the production-smoothing model is that there are costs of adjusting the level of production in a firm and that these costs rise in proportion to the extent of the adjustment. The central prediction of the production-smoothing model is that, at least to the extent that there are fluctuations in the demand for a firm's products, its production will vary less than its sales, and when its sales are high, inventories will be reduced. If all firms behave this way, we should see, for the economy as a whole: (1) GDP less volatile than final sales and (2) a negative correlation between final sales and inventory investment.

The Dilemma with Inventories as a Buffer Against Changes in Sales. There are two difficulties with the production-smoothing model (Table 1). The first row of the first column shows a measure of the volatility - the standard deviation - of the businesscycle component of GDP. The first rows of the next two columns report the relative volatility of final sales and net inventory investment. The relative volatility of final sales is the ratio of the standard deviation of final sales divided by that of GDP itself. This gives us a measure of how much sales fluctuate relative to GDP. For example, we see that the relative volatility of final sales is 82 percent of that of GDP. At least at the aggregate level, production is more volatile than sales.

In the third row of the second column, we also find that the correlation between final sales and inventory investment is actually positive. Both the higher variability of production and this correlation contradict the predictions of the basic production-smoothing model described above. If production is more volatile than sales, inventories are not effective in smoothing production. This evidence - which also holds for countries other than the U.S. and for individual industries and even for firms —offers no support for the view that smoothing production is an important motive for holding inventories.

\section{Attempts to Adapt the}

Model to Fit the Facts. By adjusting the production- smoothing model to fit the data, both Valerie Ramey and Martin Eichenbaum have developed solutions to the problems with the basic production-smoothing model.
In her paper, Ramey suggests that firms may actually prefer to bunch their production because unit costs fall as they produce more. This is known as increasing returns. Ramey and Daniel Vine studied an interesting example of increasing returns in the automobile industry that is a result of contracts between manufacturers and labor unions. They argued that these contracts broadly imply that if an automobile manufacturer employs workers for less than 40 hours in any given week, it must also pay them 85 percent of the earnings lost in working less than a full week, but only if the workers work at all. ${ }^{4}$

Consider the following example, which highlights the implications of such a wage contract. Assume that an automobile manufacturer sells 75 cars a week. If its workers work a full week (40 hours), they produce 100 cars.

${ }^{4}$ Thus, if a worker is paid $\$ 10$ an hour and is employed full time for 40 hours, he is paid $\$ 400$ for the week. However, if he is employed for 35 hours, he is paid $\$ 350$ for the time he worked and 85 percent of the $\$ 50$ he would have earned for the five hours he did not work or $\$ 392.50$ in total. Finally, if he does not work at all in a week, he is not paid at all.

\section{TABLE 1}

\section{GDP, Final Sales, and Inventory Investment}

\begin{tabular}{|c|c|c|c|}
\hline & GDP & Final Sales & $\begin{array}{l}\text { Net Inventory } \\
\text { Investment }\end{array}$ \\
\hline $\begin{array}{l}\text { Percent Standard Deviation } \\
\text { Relative to GDP }\end{array}$ & 1.675 & 0.824 & 0.282 \\
\hline Correlation with GDP & 1.000 & 0.951 & 0.653 \\
\hline Correlation with NII & 0.653 & 0.410 & 1.000 \\
\hline \multicolumn{4}{|c|}{$\begin{array}{l}\text { Data are quarterly U.S., } 1954.1-2002.4 \text {, seasonally adjusted and chained in } 1996 \text { dollars. GDP } \\
\text { and final sales are reported as percentage standard deviations, detrended using a Hodrick- } \\
\text { Prescott filter with a weight of } 1600 \text {. Net inventory investment in private nonfarm inventories } \\
x_{t} \text {, is detrended relative to GDP; the detrended series is }\left(x_{t}-\bar{x}_{t}\right) / \bar{y}_{t} \text {, where } \bar{x}_{t} \text { is the HP-trend } \\
\text { of the series and } \bar{y}_{t} \text { is the trend for GDP. }\end{array}$} \\
\hline
\end{tabular}


One possible production plan would be to employ all workers for only 30 hours a week. But if, instead, they are employed full time for three weeks, then laid off every fourth week, the manufacturer will have lower labor costs. Moreover, this second option implies that production varies across weeks, while sales do not. Production has become more variable than sales because of increasing returns. ${ }^{5}$

Martin Eichenbaum considers an alternative: the effect of random changes in unit costs that are independent of the quantity produced. This theory is different from the assumption of increasing returns; it does not assume that unit costs fall with quantity produced but that they rise and fall unexpectedly over time. Examples of such unexpected changes in firms' production costs include, but are not limited to, changes in input prices, such

\footnotetext{
${ }^{5}$ If the firm chooses to employ its workers for four weeks, having them work just 30 hours each week, it will have to pay them for 38.5 hours a week, or 154 hours in total, for a total cost of $\$ 1540$. If, instead, the firm has them work full time for 40 hours during the first three weeks, then lays them off during the fourth week, it has to pay them for only 120 hours, or $\$ 1200$ in total.
}

as a rise in oil prices, and poor weather. A sudden rise in oil prices that is not expected to last very long may give a transportation company an incentive to temporarily reduce its shipments. An unexpectedly cold winter will lead construction companies to defer as much building as they can. Such random changes in costs lead to random changes in production and do so independently of fluctuations in sales. Thus, production becomes more volatile, and if these cost shocks are sufficiently large, it may become more volatile than sales.

Both Ramey's increasing returns model and Eichenbaum's cost shocks model modify the productionsmoothing model, making it more consistent with the data. In each instance, the positive co-movement between final sales and inventory investment is restored, and production becomes more variable than sales.

Regardless of whether the production-smoothing model can be reconciled to observation, a second difficulty remains. This model may apply to a relatively small fraction of the firms that hold inventories because the model is based on a manufacturing firm that produces, then stores as inventories, finished goods that it will sell later.

Inventories of finished manufactured goods are only 13 percent of the total stock of inventories in the economy (Table 2). The remaining two-thirds of inventories held in the manufacturing sector are intermediate inputs into production. The inventories held in the wholesale and retail sectors are largely finished goods, but production smoothing may not be best suited to explain the inventories held in these sectors. One reason is that firms in these sectors do not produce the goods they sell. ${ }^{6}$

\section{THE (S,s) MODEL OF INVENTORY ACCUMULATION}

Surprisingly, given its widespread use by macroeconomists studying inventory accumulation, the original model developed by economists to

${ }^{6}$ However, V.V. Chari of the University of Minnesota and the Federal Reserve Bank of Minneapolis and Mitchell Berlin of the Federal Reserve Bank of Philadelphia have independently noted, in separate discussions with me, that long-term relationships between sellers and manufacturers may imply that the production-smoothing model is applicable to retail and wholesale inventories. In such settings, manufacturers may store their finished goods with sellers.

\section{TABLE 2}

\section{Sectoral Distribution of Private Nonfarm Inventories}

\begin{tabular}{|l|c|c|c|c|}
\hline \multicolumn{2}{|c|}{} & $\begin{array}{c}\text { Percentage of Total } \\
\text { Stock of Inventories }\end{array}$ & $\begin{array}{c}\text { STD } \\
\text { (Inventory Investment) }\end{array}$ & $\begin{array}{c}\text { Correlation (Inventory } \\
\text { Investment, GDP) }\end{array}$ \\
\hline \multirow{3}{*}{ Manufacturing } & finished goods & 37 & 0.14 & 0.65 \\
& work in process & 13 & & \\
& materials \& supplies & 12 & & \\
& retail & 12 & 0.12 & 0.32 \\
Other & wholesale & 26 & 0.09 & 0.35 \\
\hline
\end{tabular}

Column 3, the percentages of the total stock of inventories, is taken from Ramey and West, 869, Table 4. 
explain firms' holdings of inventories was not the production-smoothing model. It was the $(\mathrm{S}, \mathrm{s})$ model first formulated by Herbert Scarf of Yale University. While macroeconomists do not commonly use this model, Alan Blinder and Louis Maccini have argued that the $(\mathrm{S}, \mathrm{s})$ model provides a natural resolution to the empirical inconsistencies of the basic production-smoothing model without relying on increasing returns or cost shocks.

The $(\mathrm{S}, \mathrm{s})$ model obtains very different predictions because adjustment costs operate differently. Instead of assuming that adjustment costs increase smoothly with changes in production, in the $(\mathrm{S}, \mathrm{s})$ model, adjustments lead to fixed costs. Moreover, instead of arising during production, these costs are incurred when a firm either orders or undertakes delivery of goods.

A firm facing such costs will tend to order the relevant goods in large quantities but infrequently. By ordering more than is needed at any one time, the firm can hold stocks of the goods, thereby avoiding fixed order costs because the firm orders less frequently. By holding these stocks of goods, the firm reduces the overall cost of ordering.

For example, consider Honda again. In deciding the size of the quarterly steel order for Honda's Ohio plant, a manager must go over last quarter's production and forecast future sales. This takes a certain amount of managerial time that is largely independent of the size of the steel order. As such, the costs of ordering steel, which include the labor costs associated with the manager's efforts, are fixed costs. These costs are reduced when the firm orders infrequently — that is, when it places orders of sufficient size so as to not have to order again for some time. In other words, Honda will hold inventories of steel to reduce the fixed costs of ordering. As Herbert Scarf proved, a firm facing such fixed costs will allow its inventories to fluctuate between an upper level labeled $S$ and a lower level labeled $s$ - hence, the conventional label (S, s). S represents the level of inventories held by the firm after it has restocked. It then allows its stock to fall over time until it reaches the threshold s. At that time, another order is placed. Sometimes, the order costs are called adjustment costs.

The $(\mathrm{S}, \mathrm{s})$ model is flexible enough to be consistent with either positive or negative correlations between sales and inventories. To see this, assume there's a short-term increase in sales across a large number of firms selling the same product. Firms will reduce their inventories to meet the rise in sales. For some firms, the net effect is to reduce inventories. For firms with already low words, inventories will tend to move with sales when the change in sales itself is large. Smaller increases in sales may be associated with a net reduction in total inventory holdings. Thus, the model predicts an interesting nonlinearity: we should expect inventories and sales to rise together when sales rise by a large amount, but the correlation may be negative for a small rise in sales. In a formal analysis of $(\mathrm{S}, \mathrm{s})$ retail inventories, Andrew Caplin proved a positive correlation between final sales and inventory investment. For the reasons described above, this positive correlation raised the variability of production above that of sales. Caplin concluded, "The (S, s) theory thus contradicts the widely held notion that retail sector inventories act as a buffer, protecting manufacturers from fluctuat-

\section{Overall, some firms will increase inventories when sales increase, while others will \\ reduce them.}

levels of inventories, this initial reduction means they reach their order threshold, s. As a result, they will adjust their inventories upward, raising them to S. Overall, some firms will increase inventories when sales increase, while others will reduce them. On average, the rise in sales could be associated with either an increase or a decrease in net inventory investment, depending on the size of the demand shock and different firms' current levels of inventories.

There is an interesting subtlety to the reasoning outlined above. A rise in the typical firm's inventories along with a rise in sales is more likely if many firms hit their re-ordering level. This is more likely to be the case when the increase in sales itself is large. Such large increases in sales move most firms to their lower threshold for inventories, causing them to readjust. In other ing sales." Caplin's work suggests that inventories may indeed destabilize the economy. However, his seminal analysis of retail sector inventories took final sales as given, rather than allowing them to be determined along with inventories, in general equilibrium. In general equilibrium, a complete assessment of the role of inventories would have to allow for feedback effects from the rest of the economy, which may change the behavior of final sales.

$(\mathrm{S}, \mathrm{s})$ Inventories in a Model of the Business Cycle. The (S, s) model of inventories provides us with a framework, broadly consistent with observation, to study the role of inventories over the business cycle. For

\footnotetext{
${ }^{7}$ See page 1396, paragraph 2, of Caplin's article.
} 
example, it allows us to examine the central question of whether inventories destabilize the economy and exacerbate the movements in GDP. In a recent paper, Julia Thomas and I did just that.

Our approach, in common with other modern macroeconomic analysis, relied on building a model of the macroeconomy in which aggregate economic variables, such as production, consumption, investment, and employment, are the result of interactions between households and firms, much as in the actual economy. The essential feature of our model is that, in keeping with modern practice, we model the decisions of individual households and firms, summing these decisions to arrive at aggregate variables for the economy as a whole.

Our model included an (S, s) model of a firm's inventory investment. Simulating our model to produce artificial business cycles, we were able to explain roughly one-half of the observed volatility of inventory investment. More important, inventory investment and final sales moved together, as in the data, and production, as a result, was more volatile than sales. We also found that the relationship between inventories and GDP is not as straightforward as you might expect.

We compared two model economies, identical in most fundamentals, but with one difference. Firms in one economy had no adjustment costs and, thus, no need to hold inventories. Firms in the second economy faced the costs of purchasing inputs and, thus, had an incentive to hold inventories using an
(S, s) rule, as described above. In this setting, we asked the question: If an economist were to observe two economies with firms and consumers that were essentially identical, but firms in one economy held higher inventory levels than firms in another economy, should we expect to observe more volatile sales in the economy with inventories?

Our answer is that there are really two effects. The first is straightforward. Remember the relationship GDP $=$ Final Sales + Net Inventory Investment. As we discussed above, net inventory investment in the data is procyclical and volatile. It is also positively correlated with final sales. This tends to raise the variability of GDP above that of final sales. Increases in final sales are associated with increases in inventory investment, and given that both rise simultaneously, GDP rises more than final sales. This effect is in our model.

However, our model identified a second effect: the introduction of inventories reduces the volatility of final sales. Firms facing adjustment costs the reason for the inventories in the first place - change production levels less frequently. This tends to offset the increase in the variability of GDP. Certainly, the introduction of inventories raised the variability of GDP directly, but there was an offsetting change in the volatility of final sales. When the first effect dominates, more inventories lead to more volatile sales and increases in the variability of GDP. In contrast, when the second effect dominates, higher levels of inventories actually reduce the volatility of sales and, thus, GDP. Which effect dominates depends on how the many parameters of our model interact; however, we often found cases where increases in the level of inventories reduced the variability of GDP.

\section{CONCLUSION}

Economics is full of puzzles, some of which take the form of disparities between the best available models and macroeconomic data. The production-smoothing model of inventory investment is an example of such a puzzle.

Inventory investment is procyclical and very volatile. Furthermore, it is positively correlated with final sales. As a result, the sum of these two objects, GDP, is more volatile than sales. The production-smoothing model assumes that since production is costly to adjust, firms hold inventories to smooth fluctuations in sales. The result is that simple versions of the model predict that production is less volatile than sales. Some recent research has focused on alternative explanations of why firms hold inventories, and this has led to a renewed emphasis on the $(\mathrm{S}, \mathrm{s})$ model of inventory investment. The (S, s) model, which replaces the assumption that production is costly to adjust with the alternative assumption that there are costs of ordering goods, may overturn our thinking of inventories as existing to buffer changes in sales. 


\section{REFERENCES}

Blinder, Alan S. and Louis J. Maccini. "Taking Stock: A Critical Assessment of Recent Research on Inventories," Journal of Economic Perspectives, 5, 1991, pp. 73-96.

Caplin, Andrew S. "The Variability of Aggregate Demand with (S, s) Inventory Policies," Econometrica, 53, 1985, pp. 1395-1410.

Eichenbaum, Martin S. "Rational Expectations and the Smoothing Properties of Inventories and Finished Goods," Journal of Monetary Economics, 14, 1984, pp. 71-96.

Khan, Aubhik, and Julia K. Thomas. "Inventories and the Business Cycle: An Equilibrium Analysis of (S, s) Policies," Federal Reserve Bank of Philadelphia Working Paper 02-20 (2002).
Prescott, Edward C. "Theory Ahead of Business Cycle Measurement," Federal Reserve Bank of Minneapolis Quarterly Review, 10, 1986, pp. 9-22.

Ramey, Valerie A. "Nonconvex Costs and the Behavior of Inventories," Journal of Political Economy, 99, 1991, pp. 306-34.

Ramey, Valerie A., and Daniel J. Vine. "Tracking the Source of the Decline in GDP Volatility: An Analysis of the Automobile Industry," University of California, San Diego Economics Department Working Paper, 2001.
Ramey, Valerie A., and K.D. West.

"Inventories," in M. Woodford and J. Taylor, eds., Handbook of Macroeconomics IB. Amsterdam: Elsevier Science, 1999, pp. 863-927.

Scarf, Herbert E. "The Optimality of $(S, s)$ Policies in the Dynamic Inventory Problem," In Mathematical Methods in the Social Sciences 1959. Proceedings of the First Stanford Symposium. Stanford, Calif.: Stanford University Press, 1959. 